\title{
FRIEDMAN, Sam; LAURISON, Daniel. The class ceiling: why it pays to be privileged. Bristol: Policy Press, 2019. 384 p.
}

Pedro Daniel Gonçalves Saraiva*

* Universidade de Coimbra - Coimbra, Portugal

Doutorando em Sociologia (bolseiro Fundação para a Ciência e Tecnologia) pdgs@outlook.pt

https://orcid.org/0000-0003-0249-2646 
No século XXI, a busca por profissões mais prestigiosas por meio da obtenção de diplomas universitários se coloca como perspectiva de ascensão a um patamar mais alto na pirâmide social. Mas será que essa é uma possibilidade real para todos? E será que a entrada para as classes mais altas está aberta a quem possui uma educação universitária ou é necessário algo mais? Em The class ceiling: why it pays to be privileged, os sociólogos Sam Friedman e Daniel Laurison abordam essas questões a partir de quatro estudos de caso em áreas profissionais distintas, nos quais se evidencia o fenómeno da reprodução e manutenção da classe alta. É feita uma apresentação do livro, seguida de uma avaliação crítica do mesmo e do seu contributo para o conhecimento científico.

Num capítulo introdutório, os autores pretendem-se focar sobre a reprodução e manutenção da classe alta, no caso do Reino Unido. No âmbito de um projeto de investigação e com base em entrevistas semiestruturadas, pretendem perceber como se realiza a mobilidade social até à classe alta e perceber se esta ascensão depende só da educação ou se existem outros fatores igualmente determinantes. Ao longo do livro, verifica-se como são perceptíveis as suas conclusões.

Os vários dados apresentados mostram que são sobretudo brancos com formação universitária, que pertencem a uma classe média-alta, que ocupam as profissões mais prestigiantes (sobretudo, profissões ligadas à medicina ou ao direito) (daqui em diante, denominados por "dominantes"). Outros segmentos da população, como pessoas de cor, elementos de minorias étnicas, mulheres e pessoas com deficiência têm muita dificuldade de atingir este tipo de profissões, apesar de ser possível o seu acesso (daqui em diante, denominados "dominados") (capítulo "Getting in").

A par com esta distinção, os rendimentos auferidos são igualmente desiguais. Os profisisonais considerados "dominados" auferem menores rendimentos que os seus colegas brancos "dominadores", sendo igualmente alvo de discriminações no exercício das suas tarefas (capítulo "Getting on”).

No seguimento desta ideia, o que poderá justificar estas diferenças entre os profisisonais? Como os autores descrevem, os elementos que auferem maiores rendimentos têm as seguintes caraterísticas gerais: vêm de famílias que pertencem à classe alta, têm uma educação em universidades prestigiantes (Oxford e Cambridge), desempenham profissões prestigiantes e trabalham em Londres, onde se aufere mais que no resto do país. Estas caraterísticas 
predominam sobretudo entre os profissionais "dominadores" (capítulo "Untangling the class pay gap").

Tendo como base quatro casos de estudo, que os autores usaram na sua investigação (canal de televisão, empresa de consultoria financeira, estúdio de arquitetura e representação), são perceptíveis as diferenças entre os trabalhadores, dentro da mesma área profissional. A começar pelas diferenças salariais, estas explicam-se pelas diferentes origens sociais (classe alta versus classes baixas e/ou minorias étnicas) e também pelas diferenças entre homens e mulheres, com os homens sempre a auferirem mais (capítulo "Inside elite firms").

No caso da representação e profissões ligadas à televisão, as distintas trajetórias de vida dos profissionais levam a diferentes relações com os trabalhos que desempenham. E aqui, os pais dos mesmos desempenham um papel muito importante. Sobretudo para aqueles que vêm de grupos sociais priveligiados (caso dos "dominadores"), que podem contar com o apoio dos pais para tentar atingir a estabilidade financeira nestas áreas. Em sentido oposto, todos aqueles que vêm de grupos sociais desfavorecidos (caso dos "dominados"), acabam por ter que desistir desta área, enveredando por outras áreas profissionais para atingir alguma estabilidade profissional (capítulo “The Bank of Mum and Dad”).

Focando a atenção em dois dos quatro casos de estudo (consultoria financeira e arquitetura), existe um processo de "patrocínio", enquanto processo informal, que serve para que os profissionais mais jovens e com menos experiência possam progredir mais rapidamente na sua carreira. Este processo que, sobretudo, favorece os profissionais "dominantes". Tendo em conta as suas origens, os funcionários em patamares mais altos ajudam os funcionários mais jovens, com origens semelhantes, passando à frente de outros colegas de origens mais desfavorecidas (caso dos profissionais “dominados") (capítulo "A helping hand").

Além deste processo, existem igualmente outras formas de discriminação entre colegas, tendo sempre por base a sua origem social. Existem vários códigos e formas de estar nestas empresas que só quem vem de origens sociais privilegiadas compreende e sente-se à vontade para segui-los, conseguindo ser aceite na sua área profissional, o que se evidencia no caso dos profissionais "dominantes". Em todos os outros casos, mesmo que tentem seguir esses códigos, acabam por não conseguir ser aceites da mesma maneira (capítulos "Fitting in" e "View form the top"). 
Dessa forma, os profissionais "dominados", percecionando a "class ceiling" (conceito central deste livro que pressupõe a existência de barreiras que devem ser ultrapassadas, para se entrar na classe alta), acabam por se "autoeliminar", não aproveitando oportunidades que surgem para ascender a este grupo restrito porque sentem que não pertencem nem se identificam com esse grupo (capítulo "Self-elmination").

Como forma de enquadramento teórico, os autores fazem uma breve reflexão sobre a obra de Pierre Bourdieu $(1994,1997,2007)$ e como esta se enquadra nas descobertas dos estudos dos investigadores, nomeadamente focando a ideia de "autoeliminação" (capítulo "Class ceilings: A new approach to social mobility").

Como palavras finais dos autores, é apresentado um resumo do que já foi sendo referido ao longo da obra, nomeadamente a ideia de que quem tem empregos ligados à classe alta poderá sempre auferir maiores ou menores rendimentos, dependendo da sua origem social. Além disso, verifica-se claramente um domínio dos homens brancos em profissões de topo, faltando mais mulheres, pessoas com deficiência, pessoas de cor e elementos de minorias étnicas nestes lugares. Existem claras normas e esquemas que permitem este domínio e manutenção desta situação.

Este é um livro interessante de ler, mas mais que ser interessante de ler, interessa perceber qual o seu contributo para o conhecimento científico. $\mathrm{Ou}$ seja, pode-se mesmo perguntar: o que é que o livro The class ceiling: why it pays to be privileged traz de novo ao conhecimento científico?

A grande inovação deste livro prende-se com apresentação da competição por empregos bem renumerados e prestigiantes, que se faz apenas entre quem tem determinadas caraterísticas, como a sua origem social. Quem vem de uma classe média-alta ou mesmo de uma classe alta, tem maiores hipóteses de ter uma carreira profissional de sucesso que os seus colegas de outras origens sociais. Também se pode apontar o maior sucesso dos homens em relação às mulheres ou ainda a discriminação que é feita a elementos de minorias étnicas, pessoas com deficiência e a pessoas de cor. Toda esta competição é feita tendo por base várias caraterísticas sociais já referidas no livro, podendo pôr em causa a meritocracia.

Existe um claro discurso que é ensinado desde a infância e adolescência às crianças e jovens de que devem estudar com vista a terem um bom emprego, 
que seja estável e que tenham uma boa renumeração. No entanto, este estudo exemplifica claramente que essa meritocracia (na qual a mobilidade social realiza-se perante o mérito de cada um de nós) não existe neste tipo de profissões. Apenas se consegue realizar a mobilidade social (nomeadamente a ascensão social para a classe alta e/ou a sua manutenção nesta classe) se as pessoas tiverem as caraterísticas sociais já referidas. Coloca-se a questão: onde está a meritocracia que permitiria aos jovens que se encontram na classe baixa ascender socialmente e ter melhores condições de vida que os seus pais? Este estudo, para profissões prestigiantes, mostra claramente que a meritocracia não existe. Não existindo, aprofundam-se ainda mais as desigualdades entre classes e consequentemente entre os dominadores (brancos de classe alta) e os dominados (mulheres, pessoas de cor, minorias étnicas, pessoas com deficiência).

Este é um estudo bastante interessante de ser analisado e que pode servir de base para outros estudos semelhantes, que podem ter em conta outras áreas como a medicina, o direito (apesar de referidas, não foram alvo de análise) ou mesmo a área de investigação que é feita nos centros de investigação, nas suas várias áreas de conhecimento.

Um livro do nosso tempo para compreender uma realidade contemporânea e por vezes invisível e que Sam Friedman e Daniel Laurison brilhantemente nos apresentam.

\section{Referências}

BOURDIEU, P. O poder simbólico. Lisboa: Difel, 1994.

BOURDIEU, P. Capital cultural, escuela y espacio social. Madrid: Siglo XXI, 1997. BOURDIEU, P. A distinção. Porto Alegre: Zouk, 2007. 